\title{
TINJAUAN YURIDIS PERLINDUNGAN HUKUM TERHADAP TANAH WAKAF YANG DILEPASKAN DEMI KEPENTINGAN UMUM
}

\section{JURISDICTION OVERVIEW OF LEGAL PROTECTION OF WAKF LAND WAS REMOVED FOR PUBLIC INTEREST}

\author{
Humaira $^{1}$, Chadijah Rizki Lestari ${ }^{2}$ \\ ${ }^{1,2}$ Universitas Syiah Kuala, Darussalam, Banda Aceh, Aceh, Indonesia.
}

\section{Email: humaira_alipiyeung@unsyiah.ac.id, chadijahrizki@unsyiah.ac.id}

\begin{abstract}
ABSTRAK
Sebagai salah satu jenis harta wakaf, tanah berperan penting untuk mencapai kesejahteraan dan peningkatan perekonomian umat. Namun, atas nama kepentingan umum, tidak jarang tanah wakaf termasuk dalam bidang tanah yang terkena pengadaan tanah. Tulisan ini untuk menjelaskan perlindungan hukum yang diberikan Negara atas tanah yang diambil untuk kepentingan umum. Metode yang digunakan adalah yuridis normatif. Pada bagian hasil pembahasan diketahui bahwa untuk kepentingan umum, tanah wakaf dapat dilepaskan berdasarkan norma fungsi sosial yang ada pada Pasal 6 UUPA. Namun, instansi yang memerlukan tanah tetap wajib mengganti tanah lain yang nilainya sama atau sekurang-kurangnya sama dengan nilai tanah wakaf sebelumnya. Selain itu, tanah penganti tesebut wajib didaftarkan untuk memperoleh perlindungan dan kepastian hukum
\end{abstract}

Kata Kunci: Perlindungan hukum, tanah wakaf, kepentingan umum 


\section{ABSTRACT}

As one type of waqf property, land plays an important role in achieving prosperity and improving the economy of the people. However, in the name of public interest, it is not uncommon for waqf land to be included in land parcels subject to land acquisition. This paper is to explain the legal protection provided by the State for land taken for the public interest. The method used is normative juridical. In the result of the discussion, it is known that for the public interest, waqf land can be released based on the social function norms contained in Article 6 of the UUPA. However, agencies that require land are still obliged to replace other land whose value is the same or at least the same as the value of the previous waqf land. In addition, the replacement land must be registered to obtain legal protection and certainty

\section{Keywords: Legal protection, wakqf land, public interest}

\section{PENDAHULUAN}

Tanah merupakan salah satu karunia Tuhan Yang Maha Esa yang dapat digunakan dalam meningkatkan taraf hidup manusia. Peruntukannya dapat dimanfaatkan di berbagai bidang kehidupan, baik perkebunan, peternakan, bahkan untuk kepentingan pembangunan baik di darat maupun di bawah laut. Pemanfaatan dan pengusahaan tanah dapat dilakukan apabila syarat-syarat penguasaan hak atas tanah telah dipenuhi serta sesuai dengan struktur dan pola ruang yangditetapkan dalam rencana umum tata ruang wilayah bersangkutan (Boedi harsono, 2007:63). Selain itu, dalam pemanfataan dan pengusahaan tanah diwajibkan pula untuk tetap memelihara kelestarian, kemampuan dan mencegah kerusakan tanah tersebut.

Bagi umat muslim, selain sebagai sumber kesejahteraan tanah juga merupakan sarana ibadah dan kepedulian sosial. Sudah menjadi pengetahuan umum bahwa tidak semua individu terlahir dalam kondisi yang sempurna, baik secara fisik maupun ekonomi. Oleh karena itu, Allah SWT menganjurkan hambanya untuk saling berbuat baik dan tolong menolong tanpa memandang ras, suku, bangsa dan agama. Salah satunya adalah dengan mewakafkan tanah untuk kepentingan umat. Melalui wakaf, kepemilikan dan hubungan antara seseorang dengan tanahnya yang sebelumnya sah secara hukum menjadi putus, dengan pengharapan bahwa perbuatan tersebut akan memperoleh ridha dan pahala dari Allah SWT.

Namun, pada kondisi tertentu tanah wakaf ternyata dibutuhkan negara untuk pembangunan demi kepentingan umum. Hal ini menyebabkan tanah wakaf berpotensi diambil (melalui proses peralihan hak) negara. Sayangnya Berdasarkan hasil penelitian pembebasan tanah menduduki masalah tertinggi kedua setelah perencanaan dan persiapan (Tanah Untuk Kepentingan 
Umum", https://kppip.go.id). Berdasarkan hal tersebut diatas maka tulisan ini akan membahas tentang bagaimanakah perlindungan hukum tanah wakaf pada Pengadaan Tanah untuk kepentingan umum.

\section{METODE PENELITIAN}

Metode yang digunakan adalah yuridis normatif dengan 3 (tiga) pendekatan yaitu pendekatan undang-undang, pendekatan konseptual, dan pendekatan sejarah.

\section{HASIL PENELITIAN DAN PEMBAHASAN}

Kata wakaf berasal dari bahasa arab waqafa yang berarti berhenti atau menahan (Tim El-Madani, et.al, 2014:101). Secara konteks, objek yang ditahan tersebut dapat berupa harta dan/atau manfaat harta pemberi wakaf (wakif) untuk disedekahkan kepada penerima wakaf. Sementara itu, menurut ketentuan Pasal 1 Angka 1 Undang-Undang Nomor 41 Tahun 2004 Tentang Wakaf (UU Wakaf), wakaf adalah "Perbuatan hukum wakif untuk memisahkan dan/atau menyerahkan sebagian harta benda miliknya untuk dimanfaatkan selamanya atau untuk jangka waktu tertentu sesuai dengan kepentingannya guna keperluan ibadah dan/atau kesejahteraan umum menurut syariah."

Selain pengertian tersebut diatas, para ahli fiqh juga mendefinisikan wakaf sesuai dengan mahzab yang dianutnya, yaitu (Abdurrahman dalam Devi Kurnia Sari, 2006 : 33:
1. Mahzab Hanafi

Wakaf adalah menyedekahkan manfaat dari harta wakif untuk kepentingan sosial, namun wakif tetap sebagai pemilik harta tersebut.

2. Mahzab Hambali

Menurut Mahzab Hambali wakaf adalah melepaskan penguasaan dan kepemilikan atas harta wakif setelah sempurnanya prosedur wakaf, untuk disalurkan manfaatnya demi tujuan kebajikan.

\section{Mahzab Maliki}

Mahzab Maliki berpendapat bahwa wakaf adalah memberikan manfaat dari hasil harta yang dimiliki wakif kepada pihak penerima wakaf untuk jangka waktu tertentu sesuai dengan kehendak wakif.

Berdasarkan beberapa pengertian tersebut diatas, penulis menyimpulkan wakaf sebagai perbuatan hukum wakif memisahkan harta benda bendanya (sejumlah yang diinginkan oleh wakif) agar bermanfaat bagi penerima wakaf, baik bersifat sementara maupun untuk selamanya.

Termasuk ke dalam harta benda wakaf menurut Pasal 16 UU Wakaf adalah:

1. Benda tidak bergerak

a. Hak atas tanah sesuai dengan ketentuan peraturan perundangan yang berlaku baik yang sudah maupun yang belum terdaftar 
b. Bangunan atau bagian bangunan yang berdiri diatas tanah sebagaimana dimaksud pada huruf a

c. Tanaman dan benda lain yang berkaitan dengan tanah

d. Hak milik atas satuan rumah susun sesuai dengan ketentuan peraturan perundang-undangan yang berlaku

e. Benda tidak bergerak lain sesuai dengan ketentuan syariah dan peraturan perundang-undangan yang berlaku.

2. Benda bergerak selain uang

1. Benda digolongkan sebagai benda bergerak karena sifatnya yang dapat berpindah atau dipindahkan, yaitu:

a. Kapal;

b. Pesawat terbang;

c. Kendaraan bermotor;

d. Mesin atau peralatan industri yang tidak tertancap pada bangunan;

e. Logam dan batu mulia; dan/atau

f. Benda lainnya yang tergolong sebagai benda bergerak karena sifatnya dan memiliki manfaat jangka panjang .

2. Benda bergerak karena peraturan perundang-undangan sepanjang tidak bertentangan dengan prinsip syariah, yaitu:

a. Surat berharga yang berupa:

1. Saham;

2. Surat hutang Negara;

3. Obligasi pada umumnya; dan/atau

4. Surat berharga lainnya yang dapat dinilai dengan uang. b. Hak atas kekayaan intelektual yang berupa:

1. Hak cipta;

2. Hak merek

3. Hak paten

4. Hak desain industry

5. Hak rahasia dagang

6. Hak sirkuit terpadu

7. Hak perlindungan varietas tanaman; dan/atau

8. Hak lainnya.

c. Hak atas benda bergerak lainnya yang berupa:

1. Hak sewa, hak pakai, dan hak pakai hasil atas benda bergerak; atau

2. Perikatan, tuntutan atas jumlah uang yang dapat ditagih atas benda bergerak.

3. Benda bergerak berupa uang yang bentuk mata uang rupiah.

Wakaf dikatakan sah apabila memenuhi unsur-unsur sebagaimana ditentuan Pasal 6 UU Wakaf, yaitu:

a. Wakif;

b. Nazhir;

c. Harta benda wakaf;

d. Harta benda wakaf;

e. Peruntukan harta benda wakaf;

f. Jangka waktu wakaf.

Lebih khusus, Pasal 223 Kompilasi Hukum Islam (KHI) menyebutkan tentang tata cara pelaksanaan wakaf, yaitu: 
1. Pihak yang mewakafkan dapat menyatakan ikrar wakaf di hadapan Pejabat Pembuat Akta Ikrar Wakaf (PPAIW) untuk melaksanakan ikrar wakaf.

2. Isi dan bentuk Ikrar Wakaf ditetapkan oleh Menteri Agama

3. Pelaksanaan ikrar, demikian pula pembuatan Akta Ikrar Wakaf, dianggap sah jika dihadiri dan disaksikan oleh sekurang-kurangnya 2 (dua) orang saksi.

4. Dalam melaksanakan ikrar seperti dimaksud ayat (1) pihak yang mewakafkan diharuskan menyerahkan kepada PPAIW surat-surat sebagai berikut:

a. Tanda bukti kepemilikan harta benda;

b. Jika benda yang diwakafkan berupa benda yang tidak bergerak, maka harus disertai surat keterangan dari kepala desa, yang diperkuat oleh camat setempat yang menerangkan pemilikan benda tidak bergerak dimaksud;

c. Surat atau dokumen tertulis yang merupakan kelengkapan dari benda tidak bergerak yang bersangkutan.

\section{Konsep Perlindungan Hukum}

Sebagai makhluk sosial, setiap orang selalu membutuhkan orang lain untuk meningkatkan kualitas hidupnya. Melalui komunikasi dan interaksi yang dilakukan secara berkelompok, maka seseorang berpeluang untuk terpenuhi kebutuhan hidupnya, seperti keamanan, ketertiban, keadilan, kerjasama, dan kesejahteraan (pengertian-arti-manusia-sebagaimakhlu, edukasippkn.com). Namun untuk menjamin tercapainya tujuan tersebut, diperlukan seperangkat aturan atau norma yang mengatur perlindungan hukum sesama anggota masyarakat.

Menurut CST Kansil, perlindungan hukum merupakan berbagai upaya pemberian rasa aman yang diberikan seluruh anggota masyarakat terhadap segala gangguan dan ancaman dari berbagai pihak (CST Kansil dalam sudut hukum, perlindungan hukum, www.suduthukum.com). Sedangkan Setiono mengungkapkan bahwa perlindungan hukum adalah tindakan untuk melindungi masyarakat dari kesewenang-wenangan penguasa yang tidak sesuai dengan aturan yang berlaku untuk mewujudkan ketentraman dan ketertiban umum (Soetino, 2021).

Bentuk dari perlindungan hukum tersebut dapat berupa tindakan pemerintah yang bersifat preventif dan represif, dimana masing-masing sifat memiliki ciri khasnya masing-masing. Jika pada perlindungan hukum preventif peraturan perundang-undangan yang dihasilkan bertujuan untuk mencegah terjadinya pelanggaran atau 
sengketa, maka perlindungan hukum represif hadir untuk menyelesaikan permasalahan yang telah terjadi (Soetino dalam ilmu hukum, 2021).

\section{Pengadaan Tanah Untuk Kepentingan} Umum.

Peristilahan pengadaan tanah muncul sejak tahun 1993 bertepatan saat Presiden mengeluarkan Keppres Nomor 55 Tahun 1993 Tentang Pengadaan Tanah Bagi Pelaksanaan Pembangunan Untuk Kepentingan Umum. Kemudian disebut juga dalam Perpres Nomor 36 Tahun 2005 Jo Perpres Nomor 65 Tahun 2006 tentang Perubahan atas Peraturan Presiden Nomor 36 Tahun 2005 tentang Pengadaan Tanah bagi Pelaksanaan Pembangunan Untuk Kepentingan Umum, lalu dalam UndangUndang Nomor 2 Tahun 2012 Jo Undang Undang Nomor 11 Tahun 2020 Tentang Cipta Kerja. Pengertian pengadaan tanah dapat ditemukan pada Pasal 1 Angka 2 UU No. 2 Tahun 2012 Tentang Pengadaan Tanah, yaitu "Kegiatan menyediakan tanah dengan cara memberikan ganti rugi yang layak dan adil kepada pihak yang berhak."

Sedangkan istilah kepentingan umum merujuk pada kesejahteraan bersama dari masyarakat. Definisinya sendiri bisa terus berubah berdasarkan kondisi dan waktu di setiap keadaan (Kepentingan publik, dpmpd.kaltimprov.go.id). Bagir Manan mendefinisikan kepentingan umum sebagai "kepentingan orang banyak yang untuk mengaksesnya tidak mensyaratkan beban tertentu”. Di sisi lain, Maria S.W Sumardjono selain dapat dirasakan kemanfaatannya, kepentingan umum juga harus dirasakan manfaatnya secara menyeluruh (Kepentingan Publik, dpmpd.kaltimprov.go.id).

5. Perlindungan Hukum Tanah Wakaf Pada Pengadaan Tanah Untuk Kepentingan Umum.

Negara sebagai organisasi masyarakat tertinggi, memiliki tugas untuk menciptakan keamanan, ketertiban, dan kemakmuran bagi rakyatnya. Untuk itu negara berkewajiban menyelenggarakan pembangunan di segala aspek kehidupan salah satunya pembangunan fisik yang dilaksanakan berdasarkan ketentuan UUD 1945 dan hukum tanah nasional. Suksesnya kegiatan tersebut tentu sangat bergantung pada ketersediaan tanah yang jumlahnya tidak sedikit. Di sisi lain, tanah tanah yang ada pada saat ini sudah melekat sesuatu hak diatasnya yang pada UUPA disebut sebagai hak milik, hak guna bangunan, hak guna usaha, hak pakai, dan tanah wakaf.

Namun, hal ini tidak dapat djadikan sebagai alasan pembangunan tidak dapat dilaksanakan. Berdasarkan ketentuan Pasal 33 ayat (3) UUD 1945 diketahui bahwa negara menguasai bumi, air dan kekayaan alam yang terkandung didalamnya. Penguasaan ini dimaknai lagi dalam Pasal 2 UUPA dengan tetap menghormati dan mengakui hak 
masyarakat atas tanah serta benda yang berkaitan dengan tanah. Keseimbangan perhatian antara 2 (dua) kepentingan (perseorangan dan umum) dapat berimplikasi pada kesejahteraan bagi seluruh rakyat Indonesia (Rahayu Subekti: 2016, 377).

Selanjutnya dalam Pasal 6 UUPA disebutkan bahwa "semua hak atas tanah mempunyai fungsi sosial." Hal inilah yang menyebabkan pemegang hak atas tanah harus merelakan tanahnya untuk kepentingan umum, yang dalam hal ini disebut dengan istilah pengadaan tanah. Menurut Pasal 1 Angka 2 Undang-Undang Nomor 2 Tahun 2012 Tentang Pengadaan Tanah Bagi Pembangunan Untuk Kepentingan Umum, pengadaan tanah adalah "Kegiatan menyediakan tanah dengan cara memberi ganti kerugian yang layak dan adil kepada pihak yang berhak.

Penyelenggaraan pengadaan tanah ini dilakukan dengan memperhatikan keseimbangan antara kepentingan pembangunan dengan kepentingan masyarakat sebagaimana diatur dalam Pasal 9 ayat (1) UU Pengadaan Tanah. Salah satunya adalah kepentingan masyarakat terhadap tanah wakaf yang bermanfaat dalam menyelesaikan persoalan ekonomi dan membantu meningkatkan kesejahteraan masyarakat (Rachmat Djatnika dalam,A. Saepuddin, Pengembangan Potensi Wakaf di Indonesia). Pentingnya keberadaan tanah wakaf mengakibatkan tanah wakaf dilarang untuk ditukar sebagaimana diatur dalam Pasal 40 huruf f UU Wakaf.

Larangan tersebut diatas dikecualikan apabila tanah wakaf akan digunakan untuk kepentingan umum. Artinya untuk pengadaan tanah yang memerlukan tanah wakaf untuk dilaksanakan pembangunan yang disebutkan dalam Pasal 10 UU No.2 Tahun 2012 Jo UU No.11 Tahun 2020 maka tanah wakaf dapat ditukar.

Penukaran ini merupakan bentuk perlindungan hukum yang diberikan terhadap tanah wakaf yang diambil untuk kepentingan umum kepada pihak yang berhak. Menurut CST Kansil, perlindungan hukum merupakan berbagai upaya pemberian rasa aman yang diberikan seluruh anggota masyarakat terhadap segala gangguan dan ancaman dari berbagai pihak (Perlindungan hukum, www.suduthukum.com). Sedangkan Setiono mengungkapkan bahwa perlindungan hukum adalah tindakan untuk melindungi masyarakat dari kesewenang-wenangan penguasa yang tidak sesuai dengan aturan yang berlaku untuk mewujudkan ketentraman dan ketertiban umum (Teori perlindungan hukum,www. ilmuhukum. net ).

Bentuk dari perlindungan hukum tersebut dapat berupa tindakan pemerintah yang bersifat preventif dan represif, dimana masing-masing sifat memiliki ciri khasnya masing-masing. Jika pada perlindungan hukum preventif peraturan perundang-undangan yang dihasilkan bertujuan 
untuk mencegah terjadinya pelanggaran atau sengketa, maka perlindungan hukum represif hadir untuk menyelesaikan permasalahan yang telah terjadi (Pengertian arti manusia sebagai makhluk, www.edukasippkn.com).

Sebagai makhluk sosial, setiap orang selalu membutuhkan orang lain untuk meningkatkan kualitas hidupnya. Melalui komunikasi dan interaksi yang dilakukan secara berkelompok, maka seseorang berpeluang untuk terpenuhi kebutuhan hidupnya, seperti keamanan, ketertiban, keadilan, kerjasama, dan kesejahteraan (Pengertian arti manusia sebagai makhluk,www.edukasippkn.com).Namun untuk menjamin tercapainya tujuan tersebut, diperlukan seperangkat aturan atau norma yang mengatur perlindungan hukum sesama anggota masyarakat.

Terkait tanah wakaf yang akan digunakan untuk pembangunan untuk kepentingan umum, Pasal 41 ayat (2) UU Wakaf mengatur bahwa “...hanya dapat dilakukan setelah memperoleh izin tertulis dari Menteri atas persetujuan Badan Wakaf Indonesia." Prosedur yang dapat dilakukan adalah nazhir mengajukan perubahan dan/atau pengalihan harta benda wakaf dengan menyertakan dokumen persyaratan sebagaimana disebutkan Pasal 51 PP Nomor 25 Tahun 2018 untuk ditujukan kepada Menteri (dalam hal ini adalah Menteri Agama) melalui Kepala Kantor Kementerian Agama di domisili tanah wakaf berada. Setelahnya Kepala Kantor Kementerian Agama Kabupaten/Kota membentuk tim penetapan paling lambat 5 (lima) hari setelah dokumen diterima. Sebelum menerbitkan keputusan rekomendasi yang akan diserahkan kepada Menteri Agama dan BWI, tim akan mempertimbangkan pertukaran tanah wakaf tersebut benar untuk kepentingan umum berdasarkan rencana tata ruang dan tidak bertentangan dengan prinsip syari'ah dan peraturan perundang-undangan yang berlaku. Apabila pertukaran tanah wakaf dilakukan terhadap bidang tanah yang luasnya sampai dengan $5000 \mathrm{~m} 2$ (lima ribu meter persegi), Kepala Kantor Wilayah berdasarkan mandat Menteri Agama yang akan menerbitkan izin tertulis setelah memastikan bahwa Pasal 49 ayat (4) dan ayat (5) PP Nomor 25 Tahun 2018 terpenuhi. Setelahnya instansi atau pihak yang akan menggunakan tanah wajib mengajukan permohonan penerbitan sertifikat wakaf atas nama nazhir terhadap tanah pengganti kepada BPN setempat.

Pendaftaran dan penerbitan sertifikat tanah wakaf yang diajukan oleh instansi yang membutuhkan tanah dilakukan berdasarkan ketentuan Peraturan Perundang-undangan terkait Pendaftaran Tanah. Setelah mendapatkan tanah pengganti berikut dengan sertifikat tanah, nadzir kemudian melaksanakan tugasnya untuk mengelola dan mengembangkan tanah wakaf sesuai dengan tujuan perwakafan yang telah diikrarkan wakif.

\section{SIMPULAN}


Tanah Wakaf memiliki peranan penting dalam memberdayakan dan menguatkan ekonomi umat. Namun, demi kepentingan umum tanah wakaf dapat diambil oleh instansi yang memerlukan tanah untuk dibangun pembangunan berdasarkan ketentuan UU Pengadaan Tanah. Sebelum terjadi peralihan penguasaan atas tanah wakaf, nadzir berkewajiban mengajukan perubahan dan/atau pengalihan harta benda wakaf dengan menyertakan dokumen persyaratan sebagaimana disebutkan Pasal 51 PP Nomor 25 Tahun 2018. Setelah segala prosedur telah terpenuhi dan izin telah diperoleh, instansi atau pihak yang akan menggunakan tanah wajib mengajukan permohonan penerbitan sertifikat wakaf atas nama nazhir terhadap tanah pengganti kepada BPN setempat.

\section{DAFTAR PUSTAKA}

\section{a. BUKU-BUKU}

Boedi harsono, 2007, Menuju Penyempurnaan Hukum Tanah Nasional, Jakarta, Penerbit Universitas Trisakti.

Tim El-Madani, 2014, Tata Cara Pembagian Waris dan Pengaturan Wakaf, Pustaka Yustisia, Yokyakarta.

b. JURNAL

Edi Rohaedi, dkk, 2019, "Mekanisme Pengadaan Tanah Untuk Kepentingan Umum”, Pakuan Law Review Vol. 5, No. 1.

Rahayu Subekti, 2016. "Kebijakan Pemberian Ganti Kerugian Dalam Pengadaan Tanah Bagi Pembangunan Untuk Kepentingan Umum”, Yustisia, vol.5 No. 2.

c. TESIS

Devi Kurnia Sari, 2004, Tinjauan Perwakafan Tanah Menurut Undang-Undang Nomor 41

Tahun 2004 Tentang Wakaf di Kabupaten Semarang, Universitas Dipenogoro.

d. WEB

https://kppip.go.id/opini/tanah-untuk-kepentingan-umum/

http://www.edukasippkn.com/2016/01/pengertian-arti-manusia-sebagai-makhluk.html http://www.suduthukum.com/2015/09/perlindungan-hukum.html http://www.ilmuhukum.net/2015/09/teori-perlindungan-hukum-menurut-para.html https://dpmpd.kaltimprov.go.id/artikel/kepentingan-publik 
https://dpmpd.kaltimprov.go.id/artikel/kepentingan-publik

http://bdkbandung.kemenag.go.id/jurnal/136-pengembangan-potensi-wakaf-di-indonesia.

http://www.suduthukum.com/2015/09/perlindungan-hukum.html.

http://www.ilmuhukum.net/2015/09/teori-perlindungan-hukum-menurut-para.html.

http://www.edukasippkn.com/2016/01/pengertian-arti-manusia-sebagai-makhluk.html 